\title{
Finansal Bașarısızlıkların Tespitinde Kullanılan Altman Z Yönteminin Bulanık Mantık (Anfis) Yöntemi lle Test Edilmesi: Teknoloii ve Tekstil Sektöründe Bir Uygulama
}

\section{Selahattin KOC̣'- Sinem ULUCAN}

Makale Gönderim Tarihi: 27.04.2016

Makale Kabul Tarihi: 27.06.2016

\section{öz}

Bașarısızlık hem ișletmeyle doğrudan ilgili gruplar üzerinde hem de genel ekonomi üzerinde olumsuz etkileri vardır. Bu durum ișletme bașarısızlıklarının tespitinin önemini artırmıștır. Bu çalıșmada reel sektör ișletmelerinin bașarısızlık durumlarının tespiti amaçlanmıștır. BiST'te yer alan Tekstil ve Teknoloji endeksindeki ișletmelerin (2006-2013) verileri kullanılmıștır. Altman Z ișletmelerin bașarısızlıklarını tahmin etmede sıklıkla kullanılan bir yöntem olması sebebiyle Altman Z skorları hesaplanarak tahmin edilmeye çalıșılmıștır. Sonuç olarak ANFIS ile olușturulan modelin ișletme bașarısızlıklarının tahmininde etkin bir yöntem olduğu görülmüștür.

Anahtar Kelimeler: ANFIS, Altman Z Skoru, Firma Bașarısızlıklarının Tahmini, Tekstil ve Teknoloji Sektörü,

Yrd. Doç. Dr. Cumhuriyet Üniversitesi IïBF İșletme Bölümü, Sivas, skoc@cumhuriyet.edu.tr NOT: Bu çalıșma Cumhuriyet Üniversitesi Sosyal Bilimler Enstitüsü'nde Șubat 2016 tarihinde kabul edilen Finansal Bașarısızlıkların Altman Z ve Bulanık Mantık (Anfis) Yöntemi Ile Tespit Edilmesi: Teknoloji Ve Tekstil Sektöründe Bir Uygulama: (2006-2013) isimli Yüksek Lisans tezinden türetilmiș ve 1.Lisansüstü İșletme Öğrencileri Sempozyumu (LiOAS) 7-9 Nisan 2016 Gaziantep'de bildiri olarak sunulmuștur. Analizde kullanılan veriler bașkaları tarafından da kullanılabilir. 


\section{Testing Of Altman Z Methods Which Is Used For Detecting Of Financial Failures With Fuzzy Logic (Anfis) Technique: A Case Study On Technology And Textile Sector}

\section{ABSTRACT}

Failure has negative effects on both the groups directly concerned with the Corporation, and macroeconomics. This situation has increased the determination of the Corporation failures. In this work, it is intended the determination of failure situations by determinating the situations of real sector corporations. It is used the datas of the corporations on BIST textile and technology index (2006-2013). because of the fact that the Altman Z is a common method for forecasting the failures of the corporations, it was studied to forecast by calculating Altman Z skors. As a result, the model which was created with ANFIS succeded to forecast the corporation failure.

Keywords: ANFIS, ALTMAN Z Score, Estimation of Company Failure, Textile and Technology Sector

\section{Gíriș}

Bir firmanın finansal pozisyonu ve onun iflas etme olasılığına karșı duyarlılığı, ortaklarını etkilediği gibi kredi verenleri, çalıșanları ve iș ortaklarını da etkilemektedir. Firmaların iflas etmesi durumunda, birçok olumsuz etkiye neden olduğu için firmaların faaliyetlerini yürütmesi konusunda olumsuzlukları yönetmek için belli bir disiplin söz konusu olmuștur. Firmaların finansal durumlarını tespit etmek için yaygın olarak kullanılan hatta standart hale gelmiș oranlar bulunmaktadır. Firmaların iflas etme olasılıkların tahmin ve tespit edilmesi, gerek mikro düzeyde ortaklar ve çalıșanlar için gerekse makro düzeyde de ülkeler için ekonomik kayıpların olasına engel olabilmektedir. Firmaların finansal rasyoları, onların hisse senetlerinin, güçlü ve zayıf yönlerinin tespit edilmesinde de yaygın olarak kullanılmaktadır.

Ekonominin küreselleșmesi ve küresel krizlerin olması, iflasların artmasına neden olmaktadır. Bundan dolayı firmaların durum- 
larını daha doğru tespit etmek için çeșitli yol, yöntem ve olasılık arayıșları bașlamıștır (Dainiene ve Dagiliene, 2013). Bu çalıșmaların bir kısmı sayısal hesaplamalar, bir kısmı istatistiki yöntemler, alan araștırması, diskriminant analizleri ve regresyon analizleri kullanılarak yapılmıștır. Aziz \& Dar (2006)'a göre iflasların daha doğru bir biçimde tespit edilmesi için kullanılan yöntemlerin \%64 alan araștırması ile ilgili istatistik modellerinden, \%25'i bilgisayar paket programlarından, \%11 diğer kalan yöntemlerden olușmaktadır. Klasik istatistik yöntemlerinden ise ağırlıklı olarak diskriminant analizi ve regresyon modelleri kullanılmaktadır. Bilgisayar yazılım programları da ayrı bir araștırma alanı sunmakla birlikte, yaygın olarak kullanılan model ise problem çözme yöntemi olarak algılanan yapay sinir ağlarıdır. Bilgisayar yazılım programı olan bulanık mantık yöntemi ise yapay sinir ağları kadar yaygın olmamakla birlikte, son yıllarda iflas etme olasılıklarının değerlendirilmesinde ve çok çeșitli alanlarda hızla kullanımı artmakładır. Bulanık mantık kompleks nonlinear dinamik sistemleri tanımlamak için daha etkin çözümler sunmaktadır ki bunlarda matematiksel eșittlikler karıșıkır.

Firmaların iflas olasılıklarının tespit edilmesinde yalnızca ANFIS yöntemi kullanılmamakta aynı zamanda diskriminant analizi, faktör lojistik analizi ve yapay sinir ağları da kullanılmaktadır. Bu analiz yöntemlerinin birçoğu 1970'lerden bu yana bankaların iflas etme olasılıklarının tahmin edilmesinin üzerine yoğunlaștıkları görülmektedir. Yukarıda belirtilen analiz yöntemlerinin hemen hepsi finansal oranlar ile tanımlanmıș çok boyutlu olarak sınıflandırılıp formülize etmișlerdir. Bazı çalıșmalarda da iflas etme olasılıklarının tespitinde regresyon yöntemi (Meyer ve Pifcr, 1970; Sinkey1975), çok değișkenli diskriminant analizi (Santos et all., 2006; Shaw ve Gentry, 1988), çok değișkenli logit ve probit analizi (Hanweck, 1977; Martin, 1977), arkłanjant regresyon analizi (Korobow ve Stuhr, 1985) ve faktör analizi (West, 1985) kullanıldığı görülmektedir. Birçok model kullanılmasına rağmen hepsinde problemlerin sıralanmasında sorun olduğuna dair eleștiriler de yapılmıștır (Eisenbeis, 1977). Kolari, et al. (2002), çalıșmalarındaki değișkenlerin sınıflandırılmasında özelliklede bankaların iflas etme olasılıklarını araștırması esnasında lojistik regresyon yöntemi- 
ni kullanmıștır; oysaki Tsai (2009), iflas etme olasılığının tespitinde kullanılan oranların ve onların sınıflandırılmasını t-istatistik yöntemi ile belirlenmesinin diğer yöntemlerden daha doğru ve durağan olduğunu tespit etmiștir. Diskriminant analizinin sınırlandırılması iflas etme tahminlerinde yükselen alternatif bir model olarak kullanılmıștır Aziz ve Humayon, 2006; Cheng et all. 2006; Lin, 2009, banka iflaslarını tahmininde performans ölçümü olarak Type I ve Type II hatalarını dikkate almıșlardır.

Son yıllarda yapay sinir ağlarındaki gelișmeler, iflas etme tahmin problemlerinde öğrenen bir makine olarak takdim edilmiștir. Santemore ve Vinso Ticari bankaların ve bankacılık sisteminin bașarısızlıklarının ölçümünde yapay sinir ağları yöntemini kullanmıșlardır. Bu yöntem firmaların iflas etme olasılıklarının tahmininde istatistiki olarak kullanılan finansal rasyolardır. Altman Z modeli de çeșitli finansal oranlar ve o oranlara sabitlenmiș değerler ile sayıların çarpımı ve toplanması sonucu elde edilen değerler ile sonuca gitmeye çalıșan bir yöntemdir. Altman tarafından geliștirilen bu model 1960'lı yıllardan bașlayıp, son yıllara kadar gelen süre içerisinde iflas etme olasılıklarının tespit edilmesinde en çok kullanılan modeldir (Altman, 1968). Bu yöntemde belirlenmiș olan beș değișken çoklu diskriminant analiz yönteminde kullanılarak çok güçlü tahminler gerçekleștirilmiștir. 1980'lerin ortasından itibaren hem problemlerin sınıflandırılmasında hem de gelecekte iflas etme olasılıkların tahmin edilmesinde aktif olarak yapay sinir ağları yöntemi kullanılmıștır (Arora ve Saini, 2013). Tam and Kiang (1992), Texan Bank grubundan toplanan bir takım finansal rasyo oranları kullanarak iflas etme olasılığını ölçmüșler. Yapay sinir ağları ile yapılan tahmin çoklu diskriminant analizi ve diğer yöntemler ile yapılan tahminlerden daha güçlü sonuçlara ulașmıșlar. Shin at all. (2005) iflas tahmini için anlamlı gruplandırmalar olușturmak için yapay sinir ağları kullanmıșlar. Çalıșmalarında birçok yapay yöntemleri de iflas etme olasılıklarının tahmininde dikkate almıșlar. Araștırma sahasına giren 558 üretim yapan șirketten dokuz adet finansal oran çalıșmalarında dikkate alınmıș, fakat yapay sinir ağları temelinde dokuz adetten olușan oranlardan sadece beș adet finansal oran dikkate alınmıștır. 


\section{ANFis'e Genel Bir Bakıș}

The Adaptive Network-based Fuzzy Inference System (ANFIS), Roger Jang (1993) tarafından ileri sürülmüștür ki, bu yöntem de yaygın olarak "Bulanık Çıkarım Sistemi"ni (Fuzzy Inference Systems) kullanmaktadır. Açık olarak uyarlamalı ağlara dayanan bulanık çıkarım sistemi veya uyarlamalı sinirsel bulanık çıkarım sistemi anlamına gelmektedir. Esasen ANFIS yapısı, Sugeno tipi bulanık sistemlerin, sinirsel öğrenme kabiliyetine sahip bir ağ yapısı olarak temsilinden ibarettir. Bu ağ, her biri belli bir fonksiyonu gerçekleștirmek üzere, katmanlar halinde yerleștirilmiș düğümlerin birleșiminden olușmuștur. Bulanık çıkarım sistemi Șekil 1'deki gibi beș temel așamadan olușmaktadır (Arora ve Saini, 2013).

Șekil 1: ANFIS Ağının Yapısı (Arora ve Saini, 2013).

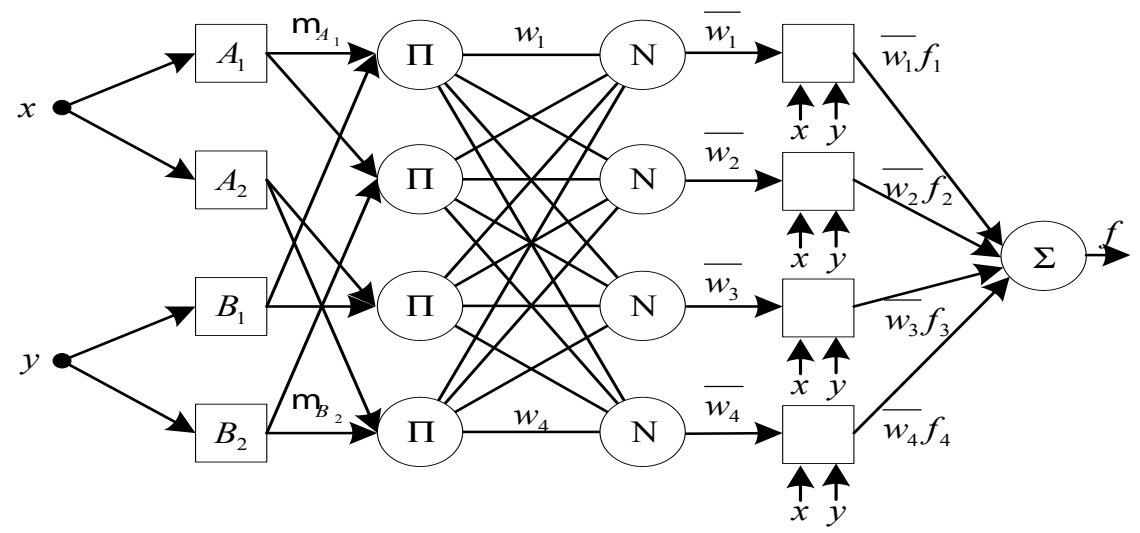

Katman 1: Bu așama girdi așamasıdır. Bu așamadaki her bir düğüm $i$ değeri bir düğüm fonksiyonu ile düğüm kareyi ifade eder. $O_{1, i^{\prime}} A_{l}$ fonksiyonunun bir üyesidir ve o verilen $x$ değerinin $A_{i}$ iyi hangi derecede karșıladığını belirtir. Biz genellikle girdi üye fonksiyonunda olduğu maksimum 1 'e minimum da $0^{\prime}$ a eșit olan çan șeklindeki üye fonksiyonu seçeriz. Giriș așaması olarak adlandırılan bu așamada her anahtar, giriș sinyallerinin diğer anahtarlara aktarıldığı giriș düğümleridir.

$$
O_{1 i}=\mu A_{i}(x) \quad i=1,2 \ldots \ldots
$$


Burada

$$
\mu A_{i}(x)=\frac{1}{1+\left[\left(\frac{x-c_{i}}{a_{i}}\right)^{2}\right]^{b i}}
$$

Burada, $a_{i}, b_{i}$ ve $c_{i}$ parametreleri olușturmaktadır. $b_{i}$ pozitif değer ve $c_{i}$ ise eğrinin merkezini göstermektedir. parametresi ile birlikte değișmektedir. Dağılımda b parametresi geçiș noktalarını a parametresiyle birlikte kontrol etmektedir. Bu parametreler değiștiğinde dağılım da bu parametrelere bağlı olarak değișmektedir.

Katman 2: Bu așama verilerin bulanıklaștırıldığı așamadır. Bu așamadaki her bir düğüm $A_{j}$ ve $B_{j}(j=1,2)$ gibi bulanık kümeleri göstermektedir. Giriș değerlerini bulanık kümelere ayırmada Jang'ın ANFIS modeli, üyelik fonksiyonu șekli olarak Genelleștirilmiș Bell üyelik fonksiyonunu kullanmaktadır. Burada her bir düğümün çıkıșı, giriș değerlerine ve kullanılan üyelik fonksiyonuna bağlı olan üyelik dereceleri vardır, 2. așamadan elde edilen üyelik dereceleri $\mu_{A i}(X)$ ve $\mu_{B i}(Y)$ değerleridir.

$$
O=W_{2 i}=\mu_{A i}(X) \times \mu_{B i}(Y) \quad i=1,2 \ldots \ldots \ldots
$$

Katman 3: Kural katmanıdır. Bu katmandaki her bir düğüm, Sugeno bulanık mantık çıkarım sistemine göre olușturulan kuralları ve sayısını ifade etmektedir. Her bir kural düğümünün çıkıșı $\mu_{i}$ ise, 2. katmandan gelen üyelik derecelerinin çarpımını ifade etmektedir. Buradaki her bir düğümün çıkıșı aynı zamanda bir kuralın ateșleme seviyesini (firing strength) göstermektedir. $\mu_{i}$ değerlerinin elde ediliși ise,

$$
Y_{i}^{3}=\Pi i=\mu A j(X) \mathrm{X} \mu B j(Y)=\mu i \quad(\mathrm{~J}=1,2) \quad(\mathrm{i}=1, \ldots \ldots, \mathrm{n})
$$

biçimindedir. Buradaki $Y_{i}^{3} 3$. așamanın çıkıș değerlerini ifade ederken $n$ ise bu katmandaki anahtar sayısını göstermektedir.

Katman 4: Normalizasyon așamasıdır. Bu katmandaki her bir düğüm, kural katmanından gelen tüm düğümleri giriș değeri olarak kabul etmekte ve bu katmanda her bir kuralın normalleștirilmiș ateșleme seviyesi hesaplanmaktadır. Normalleștirilmiș ateșleme seviyesi, i düğüm için i. kuralın ateșleme seviyesinin, bütün kuralların ateșleme seviyesine oranı olarak ifade edilmektedir. i. 
düğümün çıkıșı yani i. Düğümün normalleștirilmiș ateșleme seviyesi $\mu_{i}$ nin hesaplanması ise,

$$
y_{i}^{4}=N i=\frac{\mu_{i}}{\sum_{i=1}^{n} \mu_{i}}=\bar{\mu}_{i} \quad(\mathrm{i}=1, \ldots, \mathrm{n})
$$

biçiminde formülleștirilmektedir.

Katman 5: ANFIS ağının eğitimi, tek bașına gradyent eğim azalım algoritması ya da en küçük hata kareler yöntemi ile gradyent eğim azalım algoritmasın birleșiminden olușan tümleșik eğitim algoritması yardımıyla gerçekleștirilir. Gradyent eğim azalım algoritması tek bașına tüm parametreleri belirlemek için kullanılabilir fakat eğitim süresinin uzun olması ve bölgesel minimumlara takılma riski nedeniyle ağın eğitiminde genellikle Jang tarafından önerilen iki așamalı hibrid eğitim algoritması kullanılır (Jang, 1993). Hibrid eğitim algoritması ileri ve geri yönde olmak üzere iki așamadan olușur. Eğitimin bașında üyelik fonksiyonları tanımlanarak öncül parametrelerin ilk değerleri belirlenir. Eğitim algoritmasının ileri doğru olan geçișinde bu öncül parametreler $\left(a_{i}, b_{i}, c_{i}\right)$ sabit tutularak dördüncü katmana kadar her bir katmanın çıkıșı hesaplanır. Ardından $\left(p_{i}, q_{i}, r_{i}\right)$ soncul parametreleri en küçük hata kareler yöntemiyle elde edilir. Öncül parametreler belirli bir sabit değerde iken sistemin genel çıkıșı soncul parametrelerin doğrusal birleșimi șeklinde yazılabilir (Kaynar vd., 2011). 5. katmandaki i. düğümün çıkıș değeri ise,

$$
y_{i}^{5}=\bar{\mu}_{i}\left[p_{i} x_{1}+q_{i} x_{2}+r_{i}\right] \quad(\mathrm{i}=1, \ldots, \mathrm{n})
$$

biçimindeki eșitlikte sağlanmaktadır. Buradaki $\left(p_{i^{\prime}} q_{i} r_{i}\right)$ değișkenleri, i. kuralın sonuç parametreleri kümesidir (Șentürk, 2010).

6. Katman: Toplam değerlerin oluștuğu. Bu katmanda yalnızca bir düğüm bulunmaktadır ve $\Sigma$ ile etiketlenmiștir. Bu katmanda, 5. katmandaki her bir düğümün çıkıș değerleri toplanarak ANFIS sistemindeki gerçek değerler sağlanmıș olur. Sistemin çıkıș değeri $y^{\prime}$ nin hesaplanması ise, 


$$
y=\sum_{i=1}^{n} \bar{\mu}_{i}\left[p_{i} x_{1}+q_{i} x_{2}+r_{i}\right]
$$

Eșitliğinden sağlanmaktadır.

ANFIS'in öğrenme algoritması, hem giriș değișkenlerini hem de sonuç değișkenlerini optimize etmektedir. Belirtilen öğrenme ișlemi gerçekleșirken ANFIS melez öğrenme algoritmasını kullanmaktadır. Melez öğrenme algoritması, en küçük kareler yöntemi ile geri yayılmalı öğrenme algoritmasının birlikte kullanılmasından meydana gelmektedir. Melez öğrenme algoritması, ileri besleme ve geri besleme olmak üzere iki kısımdan olușmaktadır. Illeri besleme ve geri besleme ișlemlerinin nasıl gerçekleștiği Tablo 1'den görüldüğü gibidir (Șentürk, 2010)

\section{Tablo 1: Melez Öğrenme Algoritması}

\begin{tabular}{|l|l|l|}
\hline Melez Öğrenme Algoritması & İleri Besleme & Geri Besleme \\
\hline Giriș Parametreleri & Sabit & Geri Sayılmalı Öğrenme \\
\hline Sonuç Parametreleri & En Küçük Kareler Yöntemi & Sabit \\
\hline
\end{tabular}

\section{Modelin Formülize Edilmesi}

\subsection{Altman Z skoru ile Finansal Rasyoların Hesaplanması}

Altman Z skorunun hesaplanması ve hesaplamada kullanılan oranlar sırası ile șöyledir (Akgüç, 1989: 85).

$$
Z=1.22 X_{1}+1.4 X_{2}+3.3 X_{3}+0,6 X_{4}+0,999 X_{5}
$$

$X_{1}=$ ișletme Sermayesi/Toplam Aktifler veya Dönen Varlıklar/Toplam Aktifler (i̇șletmenin büyüklüğü ile likit varlıklar arasındaki ilișkiyi ifade eder, bu oran likidite göstergesi için kullanılmaktadır.)

$X_{2}=$ Dağıtılmayan Karlar/Toplam Aktifler (İșletmenin kazanma gücünü, gelir yaratma becerisini ölçmektedir.)

$$
X_{3}=\text { Faiz ve Vergi Öncesi Kar(FVÖK-EBIT)/Toplam Aktifler }
$$
(Karlılık göstergesi olarak kullanılmaktadır.) 
$X_{4}=$ Özkaynaklar/Toplam Borçlar (Finansal kaldıraç göstergesi olarak kullanılmaktadır. İșletmenin değerine ile ilgili izlenimleri yansitır.)

$\boldsymbol{X}_{5}=$ Satıșlar/Toplam Aktifler (Standart varlık devir hızıdır.)

Z Skoru (Z) șirketlerin mali performans trendlerinin hangi yönde olduğunu bize rakamsal olarak ifade etmektedir.

Z > 2,99' den büyük ise ișletmelerin finansal güçlükle karșilașma ihtimalinin zayıf olduğunu,

$1,81<Z<2,99$ arasındaki bir oran ișletmenin bașarısının normal seviyelerde olduğunu,

1,81> Z altındaki oranlar ise ișletmeler finansal bir güçlükle karșılașma ihtimalinin yüksek olduğunu göstermektedir.

Altman Z skoru ișletmelerin iflasa ne derecede yakın olduğunu ifade etmektedir. Finansal oranlarının ne kadar güvende olduğunu ve kısa sürede șirketleri finansal açıdan herhangi bir sorun beklenip beklenmediğini göstermektedir.

\section{Uygulama}

Bu modeli geliștirmek için MATLAB 7.0 programı içerisinde yer alan Fuzzy Logic Toolbox'ın bir fonksiyonu olarak Șekil 2 ve Șekil 3'de görüldügü üzere ANFIS GUI (Graphicaluserinterface Grafiksel kullanıcı ara yüzü) kullanılmıștır.

Șekil 2: Tekstil Endeksi İçin ANFIS Kullanıcı Arayüzü Ve Eğitim Sonuçları

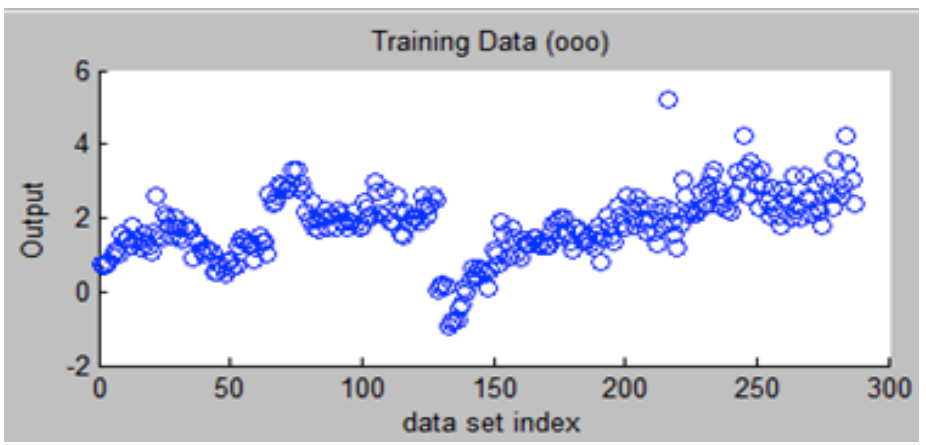


Șekil 3: Teknoloji Endeksi İçin ANFIS Kullanıcı Arayüzü Ve Eğitim Sonuçları

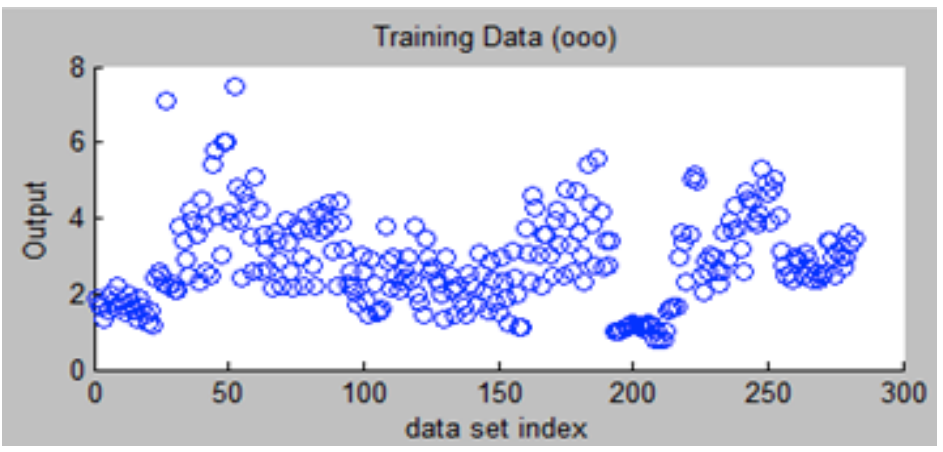

İșletme bașarısızlığı tahmin modeli olușturulurken veriler 2 ayrı veri kümesine ayrılmıștır:

- Eğitim (train) veri seti

- Test (test) veri seti

Ağı eğitmek amacıyla kullanılan eğitim veri seti için A.Zadeh ve diğ. (2009)'lerinin de önerdiği gibi tüm verilerin yaklașık \% 70 'i olan 291 veri satırı, test için tüm setin yaklașık \%30'u olan 126 veri satırı ayrılmıș ve üç ayrı dat uzantılı dosyada kaydedilmiștir.

ANFIS ekranında görülen "Veri Yükle (Load Data)" butonu kullanılarak veri kümeleri kategorilerine göre modele yüklenmiștir. Așağıda görülen Șekil 4 ve Șekil 5 'de yuvarlaklar eğitim veri setini, nokta ișaretleri ise test veri setini göstermektedir.

Șekil 4: Tekstil Endeksi Eğitim Ve Test Verilerinin ANFIS' e Yüklenmesi

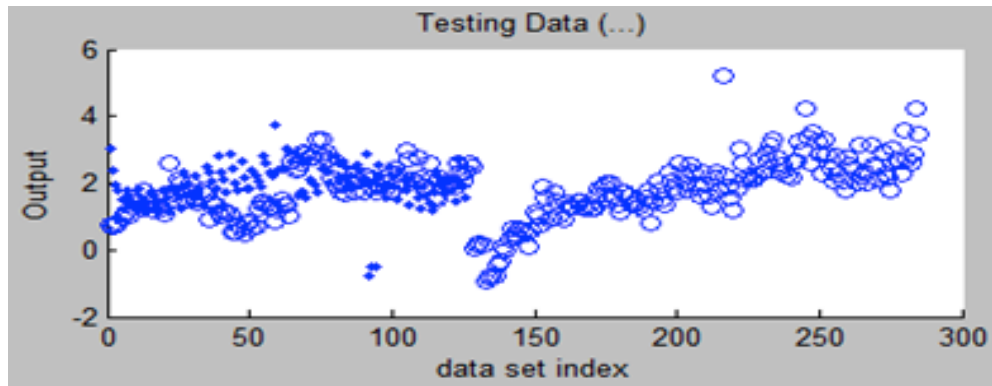


Șekil 5: Teknoloji Endeksi Eğitim Ve Test Verilerinin ANFIS' e Yüklenmesi

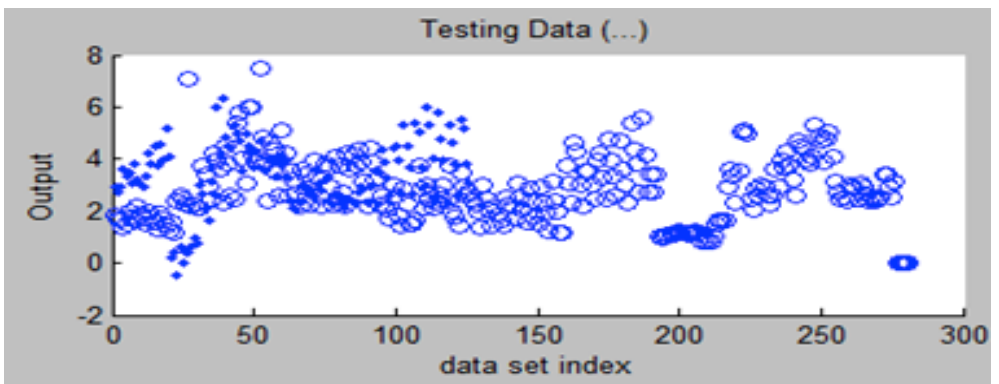

Test veri seti ile de eğitilen ve parametreleri düzenlenen modelin daha önce hiç karșılașmadığı veriler karșısında genelleme kabiliyeti ölçülmektedir.

Veri setleri yüklendikten sonra "BÇS oluștur (generate FIS)" bașlığı alında bulanık çıkarım sistemini (BÇS) olușturmak için alternatif iki yöntemden biri seçilir. Bu yöntemler:

- Izgara bölümleme (GridPartition)

- Alt Kümeleme (Sub-clustering)

Bu çalıșmada her iki yöntem için de ayrı ayrı model olușturulmuș ve olușturulan modellerden grid partition yönteminin hata kareler ortalamasının daha küçük olduğu yani daha iyi olduğu tespit edilmiștir. Bu yüzden bu çalıșmada grid partition yöntemi kullanılmıștır. 
Șekil 6:Tekstil Endeksi Alternatif Girdi /Çıkıı Üyelik Fonksiyonu Tipleri

\begin{tabular}{|l|l|}
\hline Number of MFs: & $\begin{array}{l}\text { MF Type: } \\
\text { NuT }\end{array}$ \\
$\begin{array}{l}\text { To assign a different } \\
\text { number of MFs to each } \\
\text { input, use spaces to } \\
\text { separate these numbers. }\end{array}$ & $\begin{array}{l}\text { trapmf } \\
\text { gbellmf } \\
\text { gaussmf } \\
\text { gauss } 2 \mathrm{mf} \\
\text { pimf } \\
\text { dsigmf } \\
\text { psigmf }\end{array}$ \\
\hline
\end{tabular}

Șekil 7: Teknoloji Endeksi Alternatif Girdi /Çıkıı Üyelik Fonksiyonu Tipleri

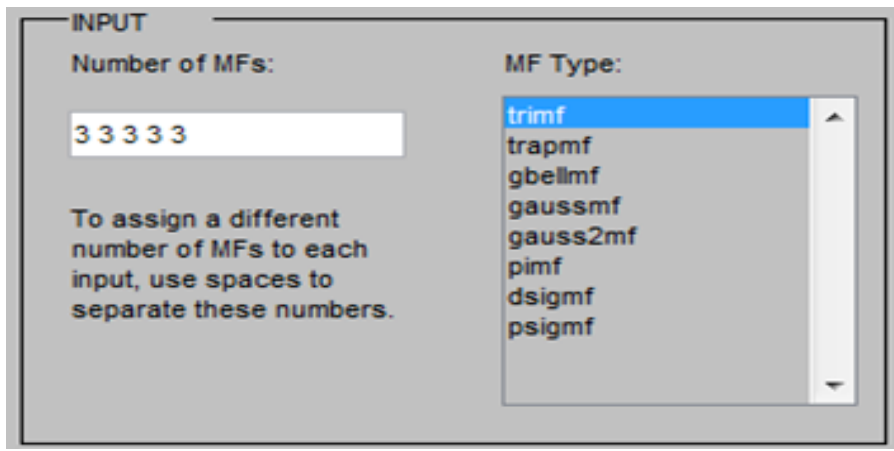

Illk olarak "ızgara bölümleme (gridpartition)" yöntemi seçildiğinde bulanık çıarım sisteminin olușturulması için Șekil 6 ve Șekil 7 'de görülen küçük ekran görülecek ve bu ekran aracilığıyla BÇS 'nin girdi üyelik fonksiyonu tipi, sayısı ve çıktı tipi belirlenir. Burada üzerinde durulması gereken önemli nokta ise en iyi sonucu bulabilmek için üyelik fonksiyon tipi ve küme sayıları denenmesi gerektiğidir. Șekil 6' da ve Șekil 7' de görüldüğü gibi üyelik sayısı 3 olacak șekilde belirlenmiștir. Optimizasyon metodu olarak da "karma (hybrid)" seçeneği seçilmiș ve "devir (epochs)" satırında da iterasyon sayısı 8 olarak belirlenmiștir. Daha sonra "ağı șimdi eğit (trainnow)" butonuna basılarak ağ eğitilmiștir. 
Ağ eğitildikten sonra test etme așamasına geçilir. Ağın ne kadar hata ile test verilerini tahmin ettiği ekranın sol alt köșesinde görülür. Eğer bu hata oranı kabul edilebilir sınırlarda ise istenilen ağ yapısına ulașıımıș demektir fakat hata oranı büyükse ağın eğitim așamasına geri dönülerek parametreler değiștirilir. İstenilen hata oranına ulașıldığı takdirde olușturulan modelin tahmin bașarısı değerlendirilir.

Elde edilen çıkı üyelik fonksiyonu değerleri tek bir çıktı değerine dönüștürülmüștür. Hem tekstil endeksi verileri hem de teknoloji endeksi verileri için uygulanan ANFIS modellemesi aynı șekildedir. Her ikisinde de en iyi sonuç bu model ile elde edilmiștir.

Șekil 8: Tekstil Endeksi ANFIS Model Yapısı

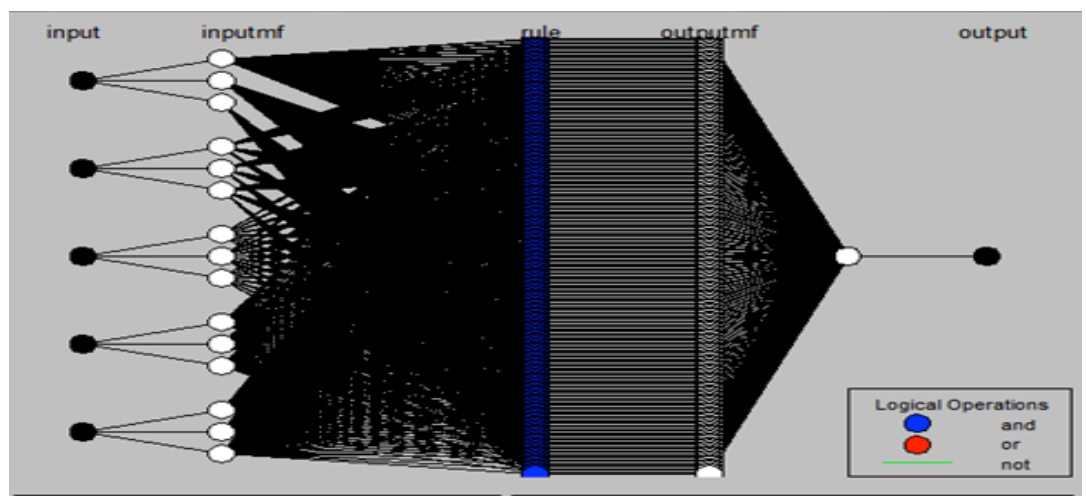

Șekil 9: Teknoloji Endeksi ANFIS Model Yapısı

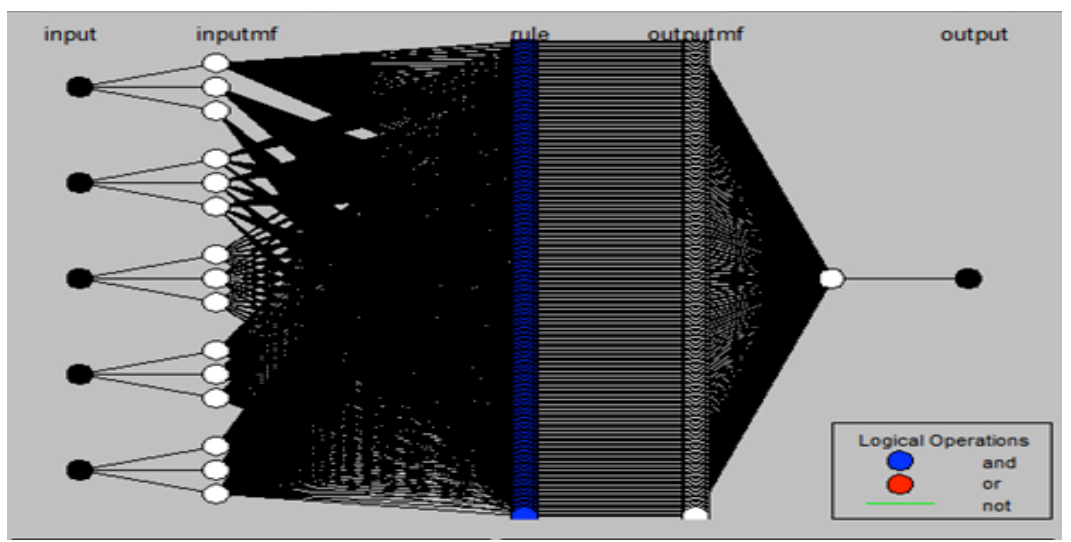


Șekil 8'de ve Șekil 9' de ise bulanık sinir ağı tarafindan olușturulan kurallar görülmektedir. Her bir giriș için 3 üyelik kümesi olduğundan 243 kural olușturulmuștur. Bu kuralları ANFIS sistemi giriș ve çıkıșlar arasındaki en iyi bağlantıyı sağlayana yani ağı eğitene kadar değiștirerek en uygun hale getirmiștir. Kural yapıları șekil 10 ve 11 'de gösterilmektedir.

\section{Șekil 10: Tekstil Endeksi ANFIS Kural Yapısı}

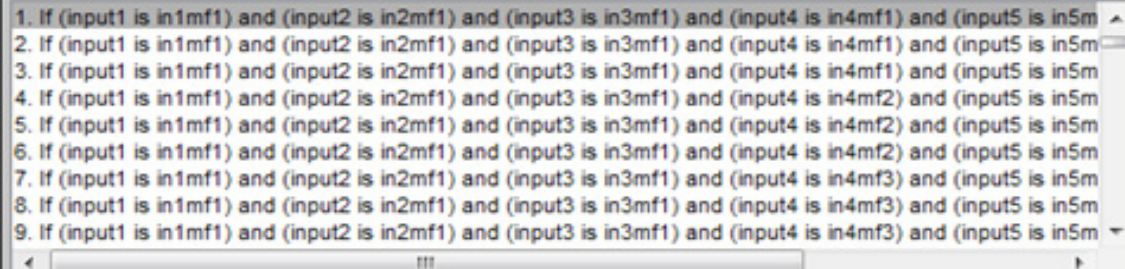

\section{Șekil 11: Teknoloji Endeksi ANFIS Kural Yapısı}

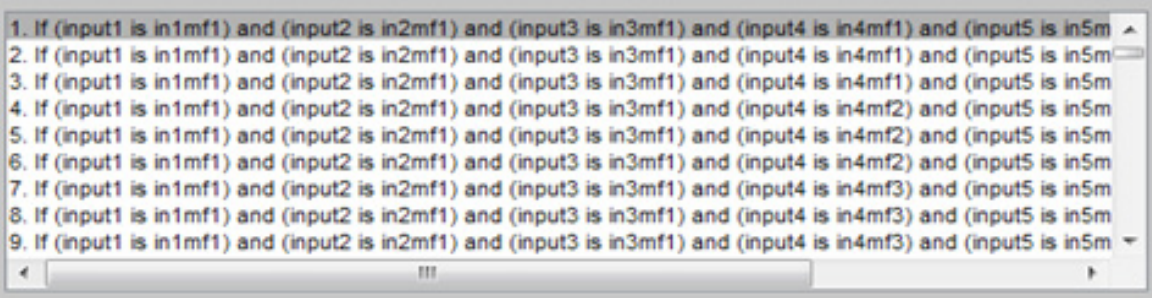

Șekil 12'de ve Șekil 13'de modelin ilk girdisi olan İșletme sermayesi / Toplam Aktif oranı verisine ilișkin üyelik fonksiyonları yer almaktadır. Düșük ve yüksek olarak tanımlanan üyelik fonksiyonları, herhangi bir değerin hangi fonksiyona hangi oranlarda ait olduğunu göstermektedir. 
Șekil 12: Tekstil Endeksi İșletme Sermayesi/Toplam Aktifler' e Ait ANFIS Üyelik Fonksiyonu

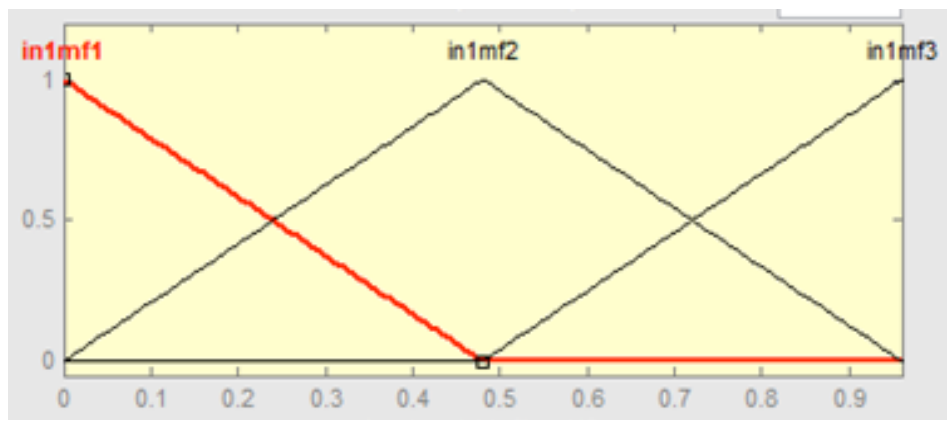

Șekil 13: Teknoloji Endeksi İșletme Sermayesi/Toplam Aktifler' e Ait ANFIS Üyelik Fonksiyonu

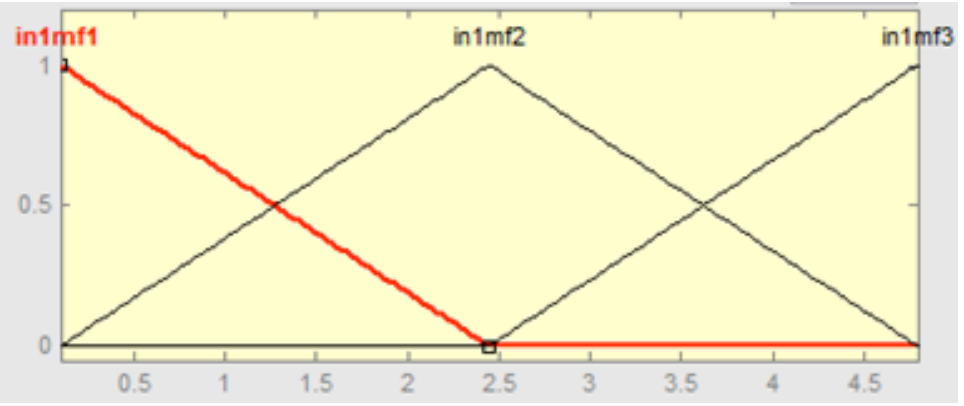

Tekstil endeksi verileri için grid yöntemi ile olușturduğumuz ağın eğitilmesi sonucu elde edilen ağın eğitim hatası RMSE (Root Mean Square Error - Ortalama hatanın karekökü) cinsinden $0,06863^{\prime}$ dür. Eğitim veri setinde gerçek değerlerle tahmin değerlerinin ne oranda çakıșığı Șekil 13'de görülmektedir. Sistem daha önce hiç görmediği veriler ile neredeyse bire bir örtüșmektedir. Bunu așağıdaki Șekil 14'da gerçek değerler ile tahmin edilen değerlerin grafiğine bakarak daha iyi anlayabiliyoruz. Mavi ve kırmızı renkli noktaların birbirine oldukça yakın olması yapılan tahminlerin doğruluğunu göstermektedir. 
Șekil 14: Tekstil Endeksi ANFIS Tahmin Sonuçları

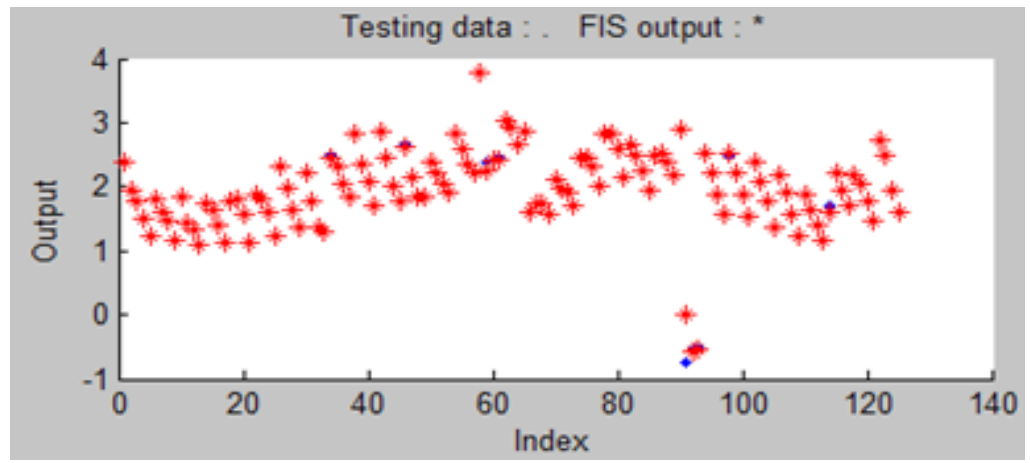

Teknoloji endeksi verileri için de kullanılan grid yöntemi ile olușturduğumuz ağın eğitilmesi sonucu elde edilen ağın eğitim hatası RMSE (Root Mean Square Error - Ortalama hatanın karekökü) cinsinden $0,13483^{\prime}$ dür. Gerçek değerler ile tahmin değerleri karșılaștığında oldukça yüksek bașarı göstermektedir. Hiç göremediği veriler ile karșılaștığında ne kadar bașarılı olduğunu așağıdaki Șekil 15'de görebiliriz. Yine aynı șekilde tekstil endeksi verileri için yapılan uygulamada olduğu gibi mavi ve kırmızı renkli noktaların birbirine oldukça yakın olması yapılan tahminlerin doğruluğunu göstermektedir.

Șekil 15: Teknoloji Endeksi ANFIS Tahmin Sonuçları

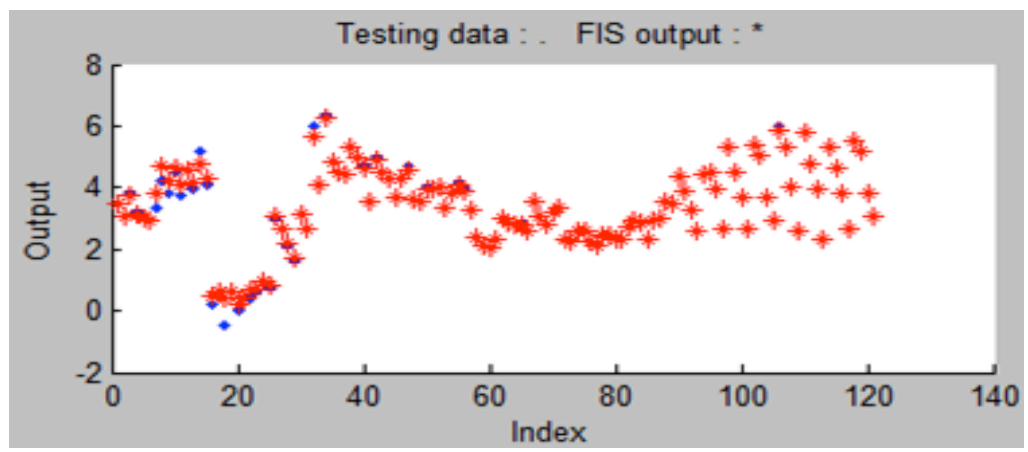


Tablo 2: Tekstil ve Teknoloji Endeksi Altman Z ANFIS Oranları

\begin{tabular}{|l|l|l|l|l|l|}
\hline TEKSTiL & $\begin{array}{c}\mathbf{2 0 0 6 - 2 0 1 3} \\
\text { (Altman Z) }\end{array}$ & $\begin{array}{c}\mathbf{2 0 0 6 - 2 0 1 3} \\
\text { (ANFiS) }\end{array}$ & \multicolumn{1}{|c|}{ TEKNOLOJi } & $\begin{array}{r}\mathbf{2 0 0 6 - 2 0 1 3} \\
\text { (Altman Z) }\end{array}$ & $\begin{array}{c}\text { 2006-2013 } \\
\text { (ANFiS) }\end{array}$ \\
\hline SÖKTAȘ & 1,410306 & 0,03634 & ASELSAN & 1,99454734 & 0,063937 \\
\hline ARSAM & 1,107979 & 0,11447 & DATEGATE & 3,99958544 & 0,28024 \\
\hline AKIN & 2,334955 & 0,046495 & INDEKS & 3,24925188 & 0,38389 \\
\hline MENDERES & 2,164331 & 0,17118 & ESCORT & 2,400834 & 0,052839 \\
\hline BIRLIK & 0,436474 & 0,073774 & ALCATEL & 2,06322851 & 0,083466 \\
\hline LÜKS & 1,462971 & 0,21505 & ARMADA & 3,611085 & 0,16902 \\
\hline KORDSA & 2,084676 & 0,11921 & ANEL & 1,860734 & 0,15496 \\
\hline BOSSA & 2,639306 & 0,022654 & LOGO & 3,724623 & 0,22333 \\
\hline DERIMOD & 2,602941 & 0,048188 & KAREL & 2,903736 & 0,13682 \\
\hline YATAȘ & 1,588633 & 0,072528 & LiNK & 2,784301 & 0,17279 \\
\hline DESA & 2,380881 & 0,071257 & PLASTiKKART & 4,637387531 & 0,044214 \\
\hline KARSU & 2,215476 & 0,21811 & NETAȘ & 2,70720845 & 0,065592 \\
\hline YÜNSA & 1,895603 & 0,14065 & ARENA & 4,21017023 & 0,1541 \\
\hline $\begin{array}{l}\text { Tekstil Endeks } \\
\text { Ortalaması }\end{array}$ & $\mathbf{1 , 8 4 6 6 8 3}$ & $\mathbf{0 , 0 6 8 6 3}$ & $\begin{array}{l}\text { Teknoloji Endeks } \\
\text { Ortalaması }\end{array}$ & $\mathbf{3 , 0 8 8 2 0 7}$ & $\mathbf{0 , 1 3 4 8 3}$ \\
\hline
\end{tabular}

Tablo 2'den de görüldüğü üzere tekstil sektörünün Altman Z değerinin 1,846683 çıkmıș olması bu sektörün karlılıklarının azaldığı, dolayısıyla bașarısız olma olasılıklarının arttığı söylenebilir. Teknoloji sektörünün Altman Z değerinin 3,088207 çıkmıș olması tekstil sektörüne göre karlılığın daha yüksek ve bașarısız olma olasılıklarının ise çok düșük olduğu ifade edilebilir.

\section{Sonuç ve Değerlendirme}

Küreselleșmenin etkisiyle ticari sınırların ortadan kalkması, ișletmelerin hem ulusal hem de uluslararası rakipleriyle sürekli rekabet içinde olmalarına neden olmuștur. Günümüzde ișletmeler devamlılıklarını sağlayabilmeleri için geçmișe oranla daha çok çaba göstermek zorundadırlar. İșletmelerin bașarılı olabilmesi için hem küresel rekabet stratejilerini iyi belirlemeleri hem de sürekli gelișen teknolojinin getirdiği, hız, standartlașma gibi yeni rekabet kavramlarından yararlanmaları gerekmektedir. İșletmelerin iç ve dıș piyasada gösterdiği performans ve yarattığı katma değer o ișletmenin rekabet gücünü göstermektedir. Rekabetin yıkıcı etkile- 
rini önceden görmek, olası iflas durumlarının önceden tespit edilmesi firmalar açısından oldukça önem arzetmektedir. Bașarısızlık durumlarının tespitinde kullanılan yöntemlerden biri de Altman Z yöntemidir. Altman Z yöntemi bir ișletmenin iflas edip etmeyeceğini \%70 güven düzeyinde 5 yıl önceden, \%96 güven düzeyinde ise 1 yıl önceden tahmin edebilmektedir (Sayılgan, 2013:206)

Bu çalıșma, son yıllarda yașanan krizler ve iflaslar sonrası reel sektör ișletmelerinin durumlarını tespit ederek varsa bir bașarısızlık durumlarını tespit etmeyi amaçlamaktadır. İșletmelerin bașarısızlıklarını tahmin edecek bir model geliștirilmesi ișletmelerin gelecekleri hakkında kararlar alabilmesi açısından önem tașımaktadır.

Tekstil sektöründe ihraçta artıș meydana gelmesine rağmen çalıșmada elde ettiğimiz 1,846683 Altman Z Skoru'na sahip Tekstil Endeksinde karlılığın azaldığı tespit edilmiștir. Bu sektörde karlılığın azalmasının nedeni olarak; Türkiye ekonomisinde tekstil sektörü rekabetçi düzeyde diğer ülkelere karșı üstün gelmesine ve ulusal geliri arttıran önemli dıș ticaret kalemi olmayı sürdürmesine karșın, dağıtım kanalı sorunları, kayıt dıșılığın yaygınlığı, dünyada kotaların kalkması dolayısıyla Çin'in olușturduğu haksız rekabet ortamı, ihracat benzerliği bulunan ülkelerin (Asya ülkeleri) maliyet avantajı uluslararası rekabetin artması, Çin'in üretimde katma değerinin artması, Rusya ile yașadığımız politik ilișkiler gibi etkenler gösterilmektedir. Tekstilcilere göre önümüzdeki yıllarda sektörü bekleyen riskler arasında kurdan dolayı fiyat verememe, pamuğun maliyetinin artması, Avrupa'da durgunluk beklentisi, Pakistan'a Avrupa Birliği'nin tanıdığı gümrük indiriminin getireceği dezavantaj arasında yer almaktadır (Güleryüz, 2011 : 65). Sektörü bekleyen en büyük riskin siparișlerin diğer ülkelerden tedarik edilebileceğine dikkat çeken tekstil sektörü temsilcilerine göre yapılacak tek șey ekonomi yönetiminin, ihracatçının global pazarlarda elini güçlendirecek kararları bir an önce alması yönünde. Bu isteklerin bașında ise kur rejiminin değiștirilmesi geliyor (Güleryüz, 2011: 71).

Tekstil sektörü Ekonomik gelișmelerden tüm sektörler gibi olumsuz etkilense de, alıcıların stoksuz çalıșması ve küçük alımlara 
yönelmesi, komșu ülkelerle ticaretin gelișmesi, 2005 sonrası Çin, $A B D$ ve Japonya'ya giriș kolaylığı, dünyanın önemli alıcılarını ülkemize çekmeyi bașarmıștır (Șahin, 2015: 160).

Teknolojik gelișme ekonomik büyümenin en önemli bileșenlerinden biridir. Teknolojik gelișmeler tüm sektörleri etkilemektedir. Piyasada önemli bir paya sahip olan teknoloji sektörü, çaIıșmada Teknoloji Endeksinden elde edilen 3,088207 Altman Z Skoru'ndan da tahmin edileceği gibi finansal açıdan bașarılı bir sektördür. Ulusal geliri artıran teknoloji sektörü yatırımcılar için önemli bir yatııı alanını olușturmaktadır.

Elde edilen sonuçlara göre Teknoloji Endeksi 3,088207 Altman Z Skoru ile 1,846683 Altman Z Skoru'na sahip Tekstil Endeksine göre daha bașarılıdır. ANFIS ile olușturulan ișletmelerin finansal yönden bașarılı ve bașarısız olma ihtimallerinin tahmin edilmesinde sistemin Tekstil Endeksi için 0,06863 ve Teknoloji Endeksi için ise 0,13483 gibi bir hata oranı ile oldukça bașarılı sonuçlar verdiği analiz sonuçlarından görülmektedir. Olușturulan bu model ile BIST Tekstil ve Teknoloji Endeksine dâhil olan ișletmelerin bașarılı ve bașarısız olma ihtimallerinin Altman Z Skoru değerleri ANFIS yöntemi kullanılarak önceden görülebileceği için olası negatif gelișmelere karșı tedbir alma imkanı sağlanabilecektir. Bu modelin sunmuș olduğu iflası belirleyen nedenler hakkındaki bulanık kurallar grubunun tutarlı olduğunu söylemek mümkündür. 


\section{KAYNAKLAR}

Akgüç, Ö. (1989), "Finansal Yönetim", Avcıol Matbaası, İstanbul.

Altman, E. I. (1968), "Financial Ratios, Discrimination Analysis and the Prediction of Corporate Bankruptcy", Journal of Finance, pp. 589-609.

Azadeha, A.,; Saberi, M.; Gitiforouz, A., . Saberi, Z. (2009), "A Hybrid Simulation-adaptive Network Based Fuzzy İnference System for İmprovement of Electricity Consumption Estimation" Expert Systems with Applications, 36, $11108-11117$

Aziz A. ve Humayon, A. (2006), "Corporate Bankruptcy: Where We Stand?", Corporate Governance, vol. 6, pp. 18-33.

Cheng, C. B.; Chen, C. L. ve Fu, C. J. (2006), "Financial Distress Prediction by a Radial Basis Function Network Withlogit Analysis Learning", Computers \& Mathematics with Applications, pp. 579-588.

Dainiene, R. ve Dagiliene, L. (2013), " Company Going Concern Evaluating Fuzzy Model" Economics and Management: 18 (3), pp. 374-383.

Eisenbeis, R. A. (1977), "Piffalls in the application of discriminant analysis in business, finance and economics", The Journal of Finance, vol. 32, no. 3, pp. 875-900.

Hanweck,G. A. (1977), "Predicting bank failures, Research Papers in Banking and Financial Economics", Financial Studies Section, Board of Governors of the Federal Reserve System, Washington, DC.

Jang, J. -S. R. (1993), "ANFIS: Adaptive-Network-Based Fuzzy Inference System", IEEE Transactions on Systems, Man and Cybernetics, vol. 23, no. 3, pp. 665-685.

Kaynar, O., Yılmaz, I., Demirkoparan, F. (2011) "Forecasting of natural gas consumption with neural network and neuro fuzzy system", Energy Education Science and Technology, PartA, Energy science and Research, 26(2), $221-238$.

Kolari, J., Glennon, D., Shin, H. ve Caputo, M. (2002) "Predicting Large US Commercial Bank Failures", Journal of Economics and Business, vol. 54, no. 321, , pp. 361-387.

Korobow L. ve Stuhr, D. (1985), "Performance Measurement of Early Warning Models", Journal of Banking \& Finance, vol. 9, Issue 2, pp. 267-273.

Lin, T. H. (2009), "A Cross Model Study of Corporate Financial Distress Prediction in Taiwan: Multiple Discriminant Analysis, Logit, Probit and Neural Networks Models", Neurocomputing, pp. 3507-3516.

Martin, D. (1977), "Early warning of Bank Failure, a Logit Regression Approach", Journal of Banking \& Finance, vol. 1, no. 3, pp. 249-276. 
Meyer, P. A. ve Pifcr, H. (1970), "Prediction of Bank failures", Journal of Finance, vol. 25, , pp. 853-868.

Ok, Y. (2010). Adaptif Sinirsel Bulanık Çıkarım Sistemi Ille Türkiye'de Orta Dönemli Elektrik Eneriisi Talep Tahmini. Ankara: Gazi Üniversitesi Fen Bilimleri Enstitüsü Yüksek Lisans Tezi

Santomero, A. M. and Vinso, J. (1977), "Estimating the Probability of Failure for Commercial Banks and the Banking System", Journal of Banking \& Finance, vol. 1, no. 2, pp. 185-205.

Santos, M. F., Cortez, P., Pereira J. ve Quintela, H. (2006), "Corporate Bankruptcy Prediction Using Data Mining Techniques", WIT Transactions on Information and Communication Technologies, vol. 37.

Sayılgan, G. (2013), "Soru ve Yanıtlarıyla İșletme Finansmanı", Güncelleștirilmiș ve Genișletilmiș 6. Baskı, Turhan Kitabevi, Ankara.

Sinkey, J. F. (1975), "A Multivariate Statistical Analysis of the Characteristics of Problem Banks", Journal of Finance, vol. 30, no. 1, pp. 21-36.

Shaw, M. J. and Gentry, J. (1988), "Using an Expert System With Inductive Learning to Evaluate Business Loans", Financial Management, vol. 17, no. 3, pp. 45-56.

Shin, K. S.; Lee, T. S. ve Kim, H. J. (2005), "An Application of Support Vector Machines in Bankruptcy Prediction Model", Expert Systems with Applications, vol. 28, pp. 127-135.

Șahin, D. (2015), "Türkiye Ve Çin'in Tekstil Ve Hazır Giyim Sektöründe Rekabet Gücünün Analizi", Akademik Bakıș Dergisi, Sayı: 47, Ss.155-171.

Șentürk, S. (2010), "Faktöriyel Tasarıma Adaptif Ağ Tabanlı Bulanık Mantık Çıkarım temi İle Farkıı Bir Yaklașım", DPÜ Fen Bilimleri Enstitüsü Dergisi, Sayı 22, ss.57-74.

Tam, K. Y. ve Kiang, M. Y. (1992), "Managerial Applications of Neural Networks: The Case of Bank Bankruptcy", OMEGA, vol. 19, no. 5, pp. 429445.

Tsai, C. F. (2009), "Feature Selection Bankruptcy Prediction", Knowledge-Based Systems, vol. 22, no. 2, pp. 120-127.

West, R. G. (1985), "A Factor-Analytic Approach to Bank Condition", Journal of Banking \& Finance, vol. 9, no. 2, pp. 253-266. 
